\title{
вмJ Global Health Health system resilience in managing the COVID-19 pandemic: lessons from Singapore
}

\author{
Alvin Qijia Chua (D) , ${ }^{1}$ Melisa Mei Jin Tan (D) , ${ }^{1}$ Monica Verma (D) , \\ Emeline Kai Lin Han, ${ }^{1}$ Li Yang Hsu (D) , ${ }^{1}$ Alex Richard Cook (D , ${ }^{1}$ Yik Ying Teo, ${ }^{1}$ \\ Vernon J Lee, ${ }^{1,2}$ Helena Legido-Quigley (D) ${ }^{1}$
}

\begin{abstract}
To cite: Chua $A Q$, Tan MMJ, Verma $\mathrm{M}$, et al. Health system resilience in managing the COVID-19 pandemic: lessons from Singapore. BMJ Global Health 2020;5:e003317. doi:10.1136/ bmjgh-2020-003317
\end{abstract}

Handling editor Seye Abimbola

Received 1 July 2020

Revised 23 August 2020

Accepted 24 August 2020
Check for updates

(c) Author(s) (or their employer(s)) 2020. Re-use permitted under CC BY-NC. No commercial re-use. See rights and permissions. Published by BMJ.

${ }^{1}$ Saw Swee Hock School of Public Health, National University of Singapore, Singapore

${ }^{2}$ Communicable Diseases Division, Ministry of Health, Singapore

Correspondence to

Alvin Qijia Chua;

alvin.chua@nus.edu.sg

\section{ABSTRACT}

Singapore, one of the first countries affected by COVID-19, adopted a national strategy for the pandemic which emphasised preparedness through a whole-of-nation approach. The pandemic was well contained initially until early April 2020, when there was a surge in cases, attributed to Singapore residents returning from hotspots overseas, and more significantly, rapid transmission locally within migrant worker dormitories. In this paper, we present the response of Singapore to the COVID-19 pandemic based on core dimensions of health system resilience during outbreaks. We also discussed on the surge in cases in April 2020, highlighting efforts to mitigate it. There was: (1) clear leadership and governance which adopted flexible plans appropriate to the situation; (2) timely, accurate and transparent communication from the government; (3) public health measures to reduce imported cases, and detect as well as isolate cases early; (4) maintenance of health service delivery; (5) access to crisis financing; and (6) legal foundation to complement policy measures. Areas for improvement include understanding reasons for poor uptake of government initiatives, such as the mobile application for contact tracing and adopting a more inclusive response that protects all individuals, including at-risk populations. The experience in Singapore and lessons learnt will contribute to pandemic preparedness and mitigation in the future.

\section{INTRODUCTION}

On 30 January 2020, WHO declared coronavirus disease 2019 (COVID-19) as an international public health emergency. Singapore, a city state of 5.7 million people, densely populated at 7866 people per square kilometre, was among the first countries affected. ${ }^{1}$ Since then, progressive measures were in place to detect and contain the disease. As of 20 August 2020, Singapore has 56099 confirmed cases, reflecting more than 50-fold increase since April, but has kept case fatality rate lower than $0.1 \%$ (27 deaths). ${ }^{2}$ The surge in cases started in early April and was attributed to Singapore residents returning from hotspots overseas,
Summary box

- Singapore was among the first countries affected by COVID-19. Its health system resilience was tested as the pandemic continued to spread following a surge in the number of infected people in early April.

- The strength in the response of Singapore to the COVID-19 pandemic was in part due to coordination between government agencies. However, we identified a few areas of improvement that may provide important learning points for other countries.

- Understanding reasons for poor uptake of initiatives, such as the mobile application for contact tracing, may help design of future initiatives that garner more public support.

- Adopting a more inclusive response that protects all individuals, including at-risk populations such as migrant workers living in dormitories, is vital to curb community transmission of outbreaks.

and more substantially, rapid transmission locally within migrant worker dormitories.

Singapore received initial recognition from WHO for its approach in COVID-19 containment. ${ }^{3}$ However, its health system resilience was tested as the pandemic continued to infect more people. Health system resilience is the ability of populations to prepare for and effectively respond to crises, by reorganising systems to manage the new conditions while maintaining core functions. ${ }^{4}$ In this paper, we present the COVID-19 pandemic response of Singapore based on core dimensions of health system resilience during outbreaks, as elaborated by Nuzzo et $a t^{4}$ and Legido-Quigley et $a l^{5}$ We have adapted the core dimensions into eight critical functions for our paper, including leadership and governance, risk communication, public health outbreak containment measures, financing, health service delivery, human resources, legal foundation, as well as political factors and values that shape the response, experiences 
and behaviours of individuals and communities during the outbreak. Considering the surge of cases since April 2020, we also reviewed its significance and highlighted interventions to contain it.

\section{LEADERSHIP AND GOVERNANCE}

The national strategy for pandemic in Singapore emphasised preparedness through a whole-of-nation approach. Since the 2003 Severe Acute Respiratory Syndrome (SARS) outbreak, nationwide efforts were implemented to prepare institutions and individuals for pandemic response. Organisations simulated possible scenarios of pandemics and developed corresponding outbreak management plans. ${ }^{6}$ A multiministry government taskforce was convened to coordinate actions between clinical and non-clinical stakeholders, centralise efforts and disseminate information. ${ }^{7}$ The taskforce, comprising heads of ministries, led and coordinated actions between different agencies. For example, Ministry of Health $(\mathrm{MOH})$ worked closely with academic institutions to provide timely epidemiological and clinical data about COVID-19 in the population. The taskforce designed and implemented measures which were guided by scientific evidence.

\section{RISK COMMUNICATION}

Clear communication channels between the government and all sectors are essential to translate policy into intended actions. The taskforce was transparent and frequent in providing situational updates, as well as new guidance and its associated rationale through traditional and social media channels, and regular press conferences. These nationwide communication channels were vulnerable to misinformation. $\mathrm{MOH}$ regularly clarified misinformation, encouraging the public to follow accurate and reliable information on official channels.

\section{PUBLIC HEALTH OUTBREAK CONTAINMENT MEASURES}

Singapore adopted a three-pronged approach to contain COVID-19: (1) reducing spread from imported cases; (2) detecting and isolating cases early; and (3) emphasising and supporting social responsibility. ${ }^{8}$

\section{Reducing spread from imported cases}

Since identification of the first imported case in Singapore, various phases of travel restrictions were implemented as the global situation worsened. Starting from outbound and inbound short-term travellers to and from China, restrictions progressively expanded to other countries internationally. ${ }^{9}$ Travellers and returnees exhibiting fever or respiratory symptoms had to undergo COVID-19 swab tests at the checkpoint. All returnees had to serve a 14-day 'Stay-Home Notice (SHN)'. ${ }^{10}$ Following a rise in number of cases linked to Singapore residents returning from hotspots overseas, the SHN was observed in dedicated facilities to reduce exposure to household members. Progressive reopening in June 2020 allowed returnees from selected countries to serve their SHN at home if they remained in those countries the last consecutive 14 days. ${ }^{11}$ Deferment of outbound travel was still advised. Short-term visitors were still not allowed entry, except for official travel permitted under special arrangements.

\section{Detecting and isolating cases early}

Singapore employed complementary detection methods when the outbreak started. ${ }^{12}$ Case definitions were based on clinical and epidemiological data, updated regularly according to evolving global situations. There was enhanced surveillance for patients with pneumonia or prolonged acute respiratory symptoms and patients in intensive care units (ICUs). Physicians were given discretion to test patients for COVID-19 based on clinical suspicion even if case definition was not fulfilled. Laboratory testing capacity was scaled up in phases, expanding to all public hospitals and major private laboratories. As of 1 June 2020, more than 408000 tests were conducted (71700 tests per million population), with plans to increase testing capacity from 8000 to 40000 tests per day. ${ }^{13}$

Individuals who tested positive were immediately isolated and interviewed for contact tracing. Contact tracing operations led by $\mathrm{MOH}$ were aided by dedicated contact tracing teams at the hospitals, the Singapore Armed Forces (SAF) and the Singapore Police Force. ${ }^{14}$ Hospital contact tracers interviewed confirmed cases to map their activity history over the last 14 days prior to onset of symptoms, until diagnosis and isolation. This information was passed to $\mathrm{MOH}$ where their contact tracers called people whom the patient had interacted with, to fill information gaps, and to identify close contacts. Close contacts and lower-risk contacts identified were placed under quarantine and phone surveillance, respectively. More than 1300 personnel from SAF and Ministry of Defence helped trace and monitor all contacts via phone during the 14-day period, referring those who reported symptoms to hospitals..$^{15}$ Importantly, cases were isolated at hospitals or community isolation facilities, akin Fangcang hospitals in China, rather than at home where they might infect household members. ${ }^{16}$

More than 800 Public Health Preparedness Clinics (PHPCs) were activated to enhance detection and management of potential cases. PHPCs were private primary care clinics responsible for screening and referring severe cases to hospitals, while advising patients with mild influenza-like symptoms to isolate at home and prevent community transmission. PHPCs also performed COVID-19 diagnostic testing through the Swab and Send Home (SASH) programme. A web-based COVID-19 Symptom Checker helped individuals navigate care options based on their symptoms, age and travel history. ${ }^{17}$

To strengthen contact tracing efforts, the TraceTogether application was launched. ${ }^{18}$ It used Bluetooth signals exchanged between mobile phones to identify 
individuals who have come into close contact with a COVID-19 patient, thereby minimising recall limitations. The application's developer code was made publicly available. ${ }^{19}$ However, uptake was not yet sufficient to replace manual contact tracing, as only 1.1 million people (less than one-fifth of total population) have downloaded the application 2 months after its launch. ${ }^{20}$ In view that low uptake could be attributed to technical limitations of the application and necessity for a smartphone for participation, a wearable device using the same technology was developed. $^{21}$ The device was intended for nationwide distribution for universal coverage. Privacy was also an issue. Despite reassurance from the government, many still expressed concern about personal data being used for surveillance purpose. SafeEntry, a national digital location check-in system, was implemented as well. ${ }^{22}$ Individuals visiting public spaces including workplaces and social venues had to scan a Quick Response (QR) code to check-in before they were allowed entry.

\section{Emphasising and supporting social responsibility}

$\mathrm{MOH}$ consistently emphasised that social responsibility is the key to slowing transmission: practise good hand hygiene, avoid touching face unnecessarily, use masks appropriately and minimise contact with others when unwell, seek medical aid at the earliest onset of any respiratory symptoms and refrain from doctor shopping.

A series of physical distancing measures were progressively implemented prior to a nationwide partial lockdown, termed as a 'circuit breaker', in April 2020. ${ }^{23}$ Public gatherings were initially restricted to below 250, and subsequently less than ten people. Temperature screenings were required before entry to facilities, and dining venues required a seating distance of at least $1 \mathrm{~m}$ apart for unrelated parties. Ambassadors were deployed at various premises to facilitate compliance to social distancing measures. Real-time updates of crowd levels in parks and malls allowed individuals to make informed visits while maintaining social distance. Other initiatives to help individuals during the outbreak were made publicly available on official websites. ${ }^{24}$

Wearing of masks was initially encouraged only if unwell, as little evidence suggested protection for healthy individuals. Since April 2020, based on new evidence about presymptomatic and asymptomatic transmission, wearing of masks was mandatory outside the household, except for children below 2 years and adults engaged in strenuous activities such as running. ${ }^{25}$ To ensure public access to some protection, three nationwide reusable cloth mask distribution drives were conducted.

Following announcements of enhanced social distancing measures, workplaces were advised to implement business continuity plans, including work from home or team segregation arrangements. ${ }^{26}$ Other recommendations included developing plans to screen visitors and employees at work premises. Schools employed measures including suspension of large group activities and staggering of recess times. In line with the "circuit breaker' and parents telecommuting from home, full home-based learning (HBL) was implemented in April $2020 .{ }^{27}$ Limited care services were provided for parents in essential services without alternative care arrangements for their children. Midyear school holidays were brought forward from June to May, to provide a respite from the month of HBL. ${ }^{28}$

\section{HEALTH SYSTEMS FINANCING AND ECONOMIC ISSUES}

It is vital to reduce financial barriers to healthcare and encourage care-seeking behaviours during disease outbreaks if infection is suspected. When the outbreak started, the government declared that it would finance treatment costs incurred by COVID-19 patients in public hospitals. ${ }^{29}$ Most private insurers have also extended coverage for hospitalisation due to COVID-19. To deter non-compliance with guidelines, residents and long-term pass holders who disregarded travel advisories would not be subsidised at public hospitals, if admitted as suspected or confirmed COVID-19 patients within 14 days on return. ${ }^{30}$ From June 2020, all travellers entering Singapore were required to self-fund their COVID-19 tests and stay at dedicated facilities if necessary.

This pandemic threatened not only the health but also the livelihood of many. The government has committed 60 billion Singapore Dollars (SGD) ( 42.4 billion USD, $12.2 \%$ of Singapore's gross domestic product) to help businesses stay viable, preserving jobs and protecting livelihoods. ${ }^{31}$ The Quarantine Order Allowance Scheme allowed self-employed individuals or employers whose employees were serving Quarantine Orders to claim 100 SGD per day, while the Temporary Relief Fund and COVID-19 Support Grant helped low-to-middle-income Singaporeans tide through the crisis. For example, lowincome workers who have lost jobs were entitled to 800 SGD monthly for 3 months.

\section{HEALTH SERVICE DELIVERY}

Following the SARS outbreak, Singapore prioritised building a specialised infectious disease centre for outbreak management. ${ }^{12}$ The National Centre for Infectious Diseases (NCID), inaugurated in 2019, is a 330-bed purpose-built infectious diseases management facility with integrated clinical, laboratory and epidemiologic functions. It houses a screening centre, isolation and cohort wards, ICUs, laboratories, imaging facilities and operating theatres.

\section{Adaptation of care and surge capacity}

Hospitals in Singapore scaled down non-critical operations to provide both clinical and non-clinical manpower for outbreak response. Separately, the government sourced for additional manpower. The Singapore Healthcare Corps, managed by $\mathrm{MOH}$, was formed as a call for former healthcare professionals to support the healthcare workforce. ${ }^{32}$ Volunteers were referred to areas of need if there was a match with available opportunities. 
Drawing lessons from previous SARS outbreak, the government ensured adequate national stockpiles of personal protective equipment (PPE) and essential medicines for up to 6 months. ${ }^{33}$ Health Sciences Authority (HSA) granted waivers on importer's licences to accelerate PPE importation. ${ }^{34}$ Local companies initiated mask manufacturing lines and donations to alleviate supply shortage. ${ }^{35}$ Existing tests based on real-time PCR viral detection required a turnaround time of at least 3 hours. Research groups in Singapore developed point-of-care test kits capable of viral detection within minutes. ${ }^{36}$ One of which was already allowed for sale in the European Union, and have received relevant HSA approvals. ${ }^{37}$ Ventilator production was expected to scale up significantly in the months to follow. ${ }^{38}$

Avenues were explored to ensure sufficient facilities for treating patients. The capacity of NCID could be increased from 330 to over 500 beds during outbreaks. Collaboration with private and community hospitals and conversion of non-healthcare buildings to community care facilities allowed transfer of COVID-19 patients with mild symptoms for monitoring, reducing the load on public hospitals. ${ }^{39}$

\section{Maintaining core health service capabilities}

Patients with chronic conditions had their clinic appointments postponed unless immediate medical attention was required..$^{40}$ Provisions were made for patients with postponed appointments to obtain medication refills via home delivery. ${ }^{41}$ Telemedicine services, where patients could consult physicians through mobile video conferences, have expanded following an increased demand with implementation of social distancing measures. ${ }^{42}$

\section{HUMAN RESOURCES}

In Singapore hospitals, mask fitting sessions and structured training were organised to ensure appropriate handling of PPE for all deployed healthcare workers (HCWs).$^{40} \mathrm{HCW}$ s changed PPE in between care for each isolated patient, as well as during movement between a COVID-19 cohort ward and a designated clean area. Innovative solutions were developed, including the 'Swab Assurance For Everyone' (SG SAFE) booth for largescale screening of potential COVID-19 patients to protect HCWs behind the booth while reducing PPE utilisation. ${ }^{43}$ To maintain full crisis capability, team segregation within each discipline was practised, ensuring provision of continued care in the event a team was quarantined due to suspected exposure to COVID-19. Movement of HCWs between hospitals was limited to reduce cross infection. As of 4 May 2020, there were 66 COVID-19 cases among HCWs. ${ }^{44}$ Although these cases, except for one, had no established epidemiological link to indicate nosocomial transmission, and vulnerabilities of HCWs in this health crisis were clear from the experiences of other countries. ${ }^{45}$ Timely, accurate and honest reporting from hospital leadership helped alleviate concerns among
HCWs. This, together with messages of support and gratitude from the community, helped boost resolve and morale of HCWs.

\section{LEGAL FOUNDATION}

The COVID-19 (Temporary Measures) Act and COVID-19 (Temporary Measures) (Control Orders) Regulations 2020 was enforced to complement policy measures in managing the outbreak. ${ }^{46}$ This legislation allowed the government to requisition any land, undertaking or other resources for the purpose of control order. It also provided legal basis to enforce social distancing measures, such as a limitation on mass gatherings, and hold individuals as well as business owners accountable for violation.

\section{POLITICAL ENVIRONMENT AND VALUES OF THE COMMUNITY}

Initial success for COVID-19 containment was attributed to Singapore's dexterous political environment, which allowed the government space to swiftly institute measures. ${ }^{47}$ The Disease Outbreak Response System Condition (DORSCON) framework, which was part of the standing national pandemic preparedness plan, was adopted for the COVID-19 outbreak. The colour-coded framework provided guidance on outbreak severity and on the required public response to prevent and reduce impact of infections. ${ }^{48}$ The taskforce stepped up risk assessment from DORSCON Yellow to DORSCON Orange on 7 February 2020. This led to sporadic instances of public panic purchasing essential supplies. ${ }^{49}$ The prime minister made national addresses to assure Singapore residents of sufficient medical supplies and daily necessities, provide an assessment of the COVID-19 situation and urge strict adherence to containment measures. These national addresses were followed by press conferences to reinforce specific adjustments to guidelines.

Experience from previous SARS outbreak has prepared Singapore residents on what to expect and how to react. Some similar measures implemented before included school closures, temperature checks, screening for fever and travel history to affected countries and home quarantine, although at a smaller scale. In addition, Singapore residents' respect for authority, coupled with stringent regulations, has allowed smooth implementation of governmental measures. The advent of social media allowed faster information dissemination while providing a platform for community and emotional support. It has also allowed online vigilantism to become more prevalent. ${ }^{50}$ While this could aid compliance to rules, reporting potential infringements directly to the authorities have been recommended.

\section{RISE IN CASES FROM APRIL 2020}

A timeline of significant events and implementations is shown in figure 1. Despite rigorous containment and mitigation efforts, there was a sharp rise in local 


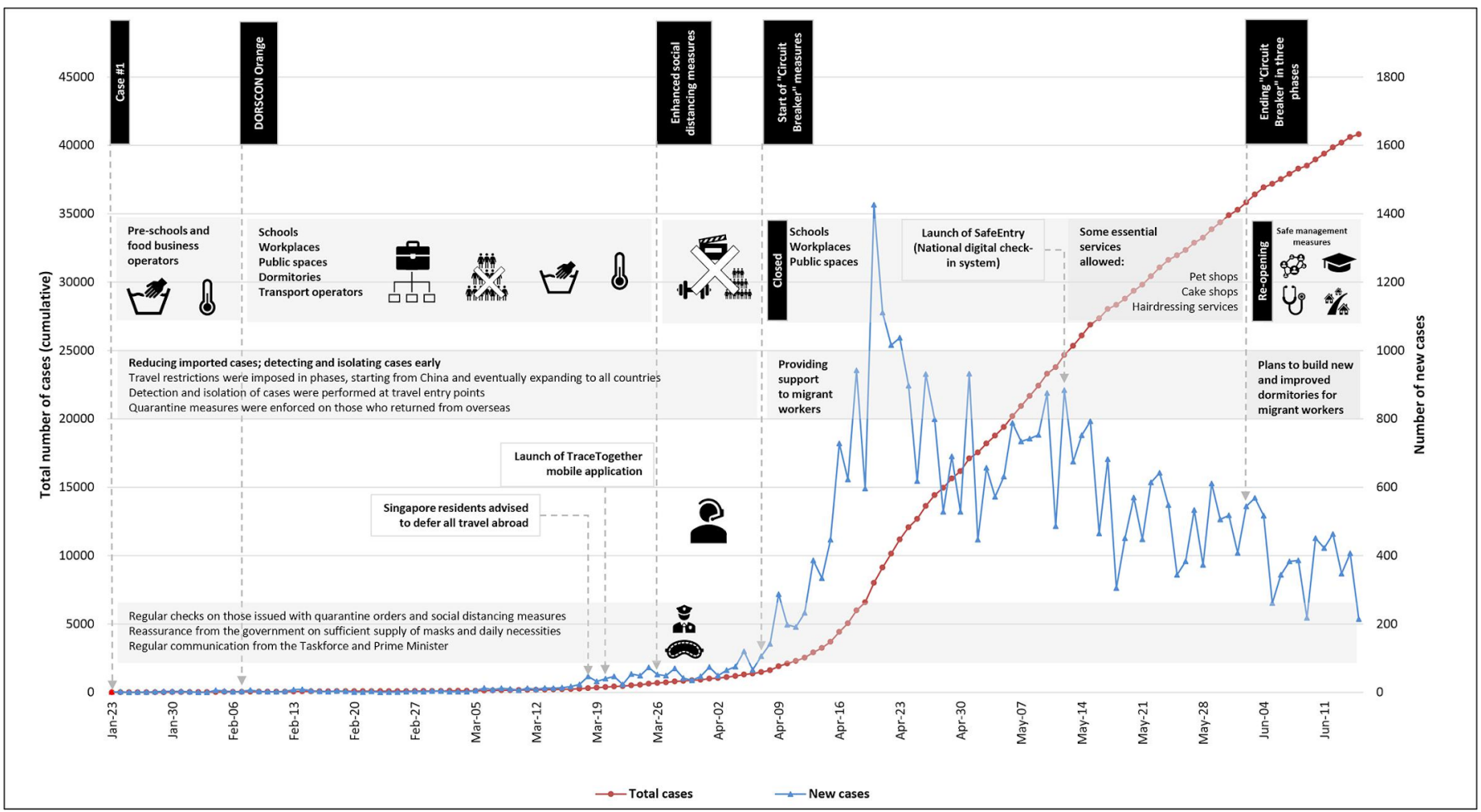

Regular handwashing
Split-work arrangements
Mass gatherings
Cinemas
Employees to telecommute
Limited visits from the same household allowed daily
Graduating cohorts to attend school daily
Others cohorts rotate between home-based learning and physical classes
Commurgent appointments for healthcare services to resume operations

Figure 1 Timeline of significant COVID-19 events and implementations in Singapore updated to June 2020. Source: Ministry of Health, Singapore. DORSCON, Disease Outbreak Response System Condition.

transmissions, likely due to imported cases, from early April 2020. On 7 April 2020, the government initiated a 1-month 'circuit breaker' measure, which was later extended for another month. ${ }^{51}$ Most workplace premises were closed, and the public were asked to stay home and avoid unnecessary outings. Schools migrated to HBL. Only essential services, including pharmacies, hospitals, clinics, supermarkets, food establishments, banking services and transport, could operate. All public gatherings were prohibited during this period. The government escalated efforts to protect the vulnerable, particularly seniors, during the 'circuit breaker' period. Volunteers were deployed to educate seniors who lived by themselves about these precautionary measures. Those who required additional support were identified and connected with relevant service providers.
A large portion of the increase was attributed to rapid transmission within migrant worker dormitories. In response, a second taskforce was set up to support this outbreak. ${ }^{52}$ Various measures were implemented to interrupt transmission in this community, including: (1) active testing of potential cases in dormitories and provision of good medical care $;^{53}$ (2) identifying new housing areas to accommodate healthy workers, ${ }^{54}$ and (3) providing translated health information to empower self-protection. By the time of writing, these measures have contained further spread of virus within the dormitories and in the community. ${ }^{55}$ However, conditions in these dormitories must be improved to prevent similar outbreaks. The government announced short-term and long-term plans for improvement. Migrant workers were housed temporarily in unused state properties, 
while the upcoming quick-build dormitories were being developed. ${ }^{56}$ These temporary accommodations were proposed to be replaced by permanent and less dense purpose-built dormitories once ready.

Singapore embarked on a planned three-phased approach to resume activities safely once the "circuit breaker' ended on 1 June $2020 .^{57}$ Phase 1 involved allowing household visits of up to two immediate family members and reopening of workplaces and schools. Those who could telecommute had to continue working from home, while students had to rotate between HBL and returning to school. Phase 2 involved resumption of most businesses that ceased operations during the "circuit breaker' and small-group gatherings of up to five people. Phase 3 would involve resumption of higher-risk activities with larger numbers of people including religious services and entertainment venues. There was no fixed duration for each phase and transition between phases was determined by community transmission rates and the testing, contact tracing and healthcare capacity.

\section{LESSONS LEARNT FROM SINGAPORE}

Four important lessons from the Singapore experience could inform future strategies in managing pandemics in other high-income countries. First, consistency and transparency in information communicated by a trusted figure and team promotes acceptability of policy measures. Concise public messages tailored to the community and cultural norms accelerate public awareness of health crises. These, in turn, facilitate public trust in leadership and cooperation in containment efforts. Next, an established and clear legal framework reduces the possibility of misinformation during crisis and enhances clarity in risk communication. Third, vigorous testing and contact tracing to identify and isolate cases promptly are important for outbreak containment. Technology helps facilitate contact tracing efforts. However, more work needs to be done to mitigate potential issues such as privacy concerns, and to design methods to improve uptake of information technology (IT)-based contact tracing tools. Providing reassurance on how contact tracing personal data will be collected, used and stored could strengthen public support. Lastly, greater emphasis on dense or at-risk populations, for example, migrant workers living in dormitories, was vital to curb community transmission of COVID-19. More efforts are required to prevent potential recurrence, including dormitory housing expansion and enhancement of migrants workers' social cohesion with the rest of the society. ${ }^{55}$ An equitable and inclusive response that protects the health and rights of all individuals, especially the most vulnerable, is necessary to overcome such crises.

\section{CONCLUSION}

We have explored the COVID-19 pandemic response of Singapore based on dimensions of health system resilience during outbreaks. There was: (1) clear leadership and governance which adopted flexible plans appropriate to the situation; (2) timely, accurate and transparent communication from the government; (3) public health measures to reduce imported cases and detect as well as isolate cases early; (4) maintenance of health service delivery; (5) access to crisis financing; and (6) legal foundation to complement policy measures. Areas for improvement include understanding reasons for poor uptake of initiatives such as the mobile application for contact tracing and adopting a more inclusive response that protects all individuals, including at-risk populations. The experience in Singapore and lessons learnt will contribute to pandemic preparedness and mitigation in the future.

Twitter Alvin Qijia Chua @alvinchuaqj, Melisa Mei Jin Tan @melisamjtan, Monica Verma@monica_v17, Li Yang Hsu @hsuliyang and Helena Legido-Quigley @legidoquigley

Contributors AQC, MMJT, MV, EKLH and HL-Q conceived the paper and prepared the initial draft. AQC led the writing process. All authors contributed to the original content and revisions to the text. All authors gave final approval of the version to be published.

Funding This research is funded through the Singapore Population Health Improvement Centre (SPHERiC) Collaborative Centre Grant from the National Medical Research Council, Singapore (NMRC/CG/C026/2017_NUHS).

Competing interests None declared.

Patient consent for publication Not required.

Provenance and peer review Not commissioned; externally peer reviewed.

Data availability statement No data are available.

Open access This is an open access article distributed in accordance with the Creative Commons Attribution Non Commercial (CC BY-NC 4.0) license, which permits others to distribute, remix, adapt, build upon this work non-commercially, and license their derivative works on different terms, provided the original work is properly cited, appropriate credit is given, any changes made indicated, and the use is non-commercial. See: http://creativecommons.org/licenses/by-nc/4.0/.

\section{ORCID iDs}

Alvin Qijia Chua http://orcid.org/0000-0001-6920-1204

Melisa Mei Jin Tan http://orcid.org/0000-0003-1620-8327

Monica Verma http://orcid.org/0000-0003-1054-0337

Li Yang Hsu http://orcid.org/0000-0002-0396-066X

Alex Richard Cook http://orcid.org/0000-0002-6271-5832

Helena Legido-Quigley http://orcid.org/0000-0003-4113-4542

\section{REFERENCES}

1 Department of Statistics Singapore. Singapore population, 2020. Available: https://www.singstat.gov.sg/modules/infographics/ population [Accessed 12 Apr 2020].

2 Ministry of Health. 20 August 2020 daily report on COVID-19, 2020. Available: https://www.moh.gov.sg/docs/librariesprovider5/2019ncov/20200820_daily_report_on_covid-19_cabinet.pdf [Accessed 21 Aug 2020].

3 TeO J. Coronavirus: WHO praises Singapore's containment of COVID-19 outbreak. The Straits Times, 2020. Available: https:// www.straitstimes.com/singapore/health/coronavirus-who-praisessingapores-containment-of-covid-19-outbreak [Accessed $12 \mathrm{Apr}$ 2020].

4 Nuzzo JB, Meyer D, Snyder M, et al. What makes health systems resilient against infectious disease outbreaks and natural hazards? Results from a scoping review. BMC Public Health 2019;19:1310.

5 Legido-Quigley H, Asgari N, Teo YY, et al. Are high-performing health systems resilient against the COVID-19 epidemic? Lancet 2020;395:848-50.

6 Lum LH, Badaruddin H, Salmon S, et al. Pandemic preparedness: Nationally-led simulation to test hospital systems. Ann Acad Med Singap 2016;45:332-7. 
7 Ministry of Health. Multi-ministry Taskforce on Wuhan coronavirus: terms of reference (TORs) and composition, 2020. Available: https:// www.moh.gov.sg/docs/librariesprovider5/default-document-library/ multi-ministry-taskforce-on-wuhan-coronavirus-and-tor---final.pdf. [Accessed 12 Apr 2020].

8 Ministry of Health. Statement by Mr Gan Kim Yong, Minister for health, at Parliament, on the update on whole-of-government response to COVID-19, 2020. Available: https://www.moh.gov.sg/ news-highlights/details/statement-by-mr-gan-kim-yong-ministerfor-health-at-parliament-on-the-update-on-whole-of-governmentresponse-to-covid-19 [Accessed 12 Apr 2020].

9 Ministry of Health. Additional border control measures to reduce further importation of COVID-19 cases, 2020. Available: https:// www.moh.gov.sg/news-highlights/details/additional-bordercontrol-measures-to-reduce-further-importation-of-covid-19-cases [Accessed 12 Apr 2020].

10 Ministry of Health. Expansion of the enhanced Stay-Home notice requirements to all countries, 2020. Available: https://www.moh.gov $\mathrm{sg} /$ news-highlights/details/expansion-of-the-enhanced-stay-homenotice-requirements-to-all-countries [Accessed 12 Apr 2020].

11 Ministry of Communications and Information. Updates to border measures for travellers entering Singapore, 2020. Available: https:// www.gov.sg/article/updates-to-border-measures-for-travellersentering-singapore [Accessed 16 Jun 2020].

12 Lee VJ, Chiew CJ, Khong WX. Interrupting transmission of COVID-19: lessons from containment efforts in Singapore. J Travel Med 2020;27.

13 Channel News Asia. More than 408,000 COVID-19 tests conducted in Singapore, 2020. Available: https://www.channelnewsasia.com/ news/singapore/covid-19-tests-singapore-community-population408000-12804984 [Accessed 5 Jun 2020].

14 Khalik S. Coronavirus: How contact tracers track down the people at risk of infection. The Straits Times, 2020. Available: https://www. straitstimes.com/singapore/health/how-contact-tracers-track-downthe-people-at-risk-of-infection [Accessed 13 May 2020].

15 Mahmud AH. SAF making thousands of calls a day to contact trace, check stay-home compliance as COVID-19 fight hits 'critical juncture'. Channel News Asia, 2020. Available: https://www. channelnewsasia.com/news/singapore/saf-contact-trace-stayhome-notice-shn-covid-19-12606752 [Accessed 13 May 2020].

16 Chen S, Zhang Z, Yang J, et al. Fangcang shelter hospitals: novel concept for responding to public health emergencies. Lancet 2020;395:1305-14.

$17 \mathrm{MOH}$ office for healthcare transformation Singapore. COVID-19 symptom checker launched to inform and help the Singapore public navigate care options, 2020. Available: https://www.moht.com.sg/ post/covid-19-symptom-checker-launched-to-inform-and-help-thesingapore-public-navigate-care-options [Accessed 12 Apr 2020]

18 Smart Nation Singapore. Launch of new app for contact tracing, 2020. Available: https://www.smartnation.gov.sg/ [Accessed $12 \mathrm{Apr}$ 2020].

19 Bay J, Kek J, Tan A, et al. Bluetrace: a privacy-preserving protocol for community-driven contact tracing across borders, 2020. Available: https://bluetrace.io/static/bluetrace_whitepaper-93806365 6596c104632def383eb33b3c.pdf [Accessed 12 Apr 2020].

20 Tham I. No other way but to make use of TraceTogether mandatory. The Straits Times, 2020. Available: https://www.straitstimes. com/singapore/no-other-way-but-to-make-use-of-tracetogethermandatory [Accessed 13 May 2020].

21 Baharudin $\mathrm{H}$. First batch of 300,000 TraceTogether devices to be made by electronics firm PCI. The Straits Times, 2020. Available: https://www.straitstimes.com/business/companies-markets/localelectronics-firm-pci-to-make-first-batch-of-wearable-tracetogether [Accessed 16 Jun 2020].

22 Government Digital Services. SafeEntry, 2020. Available: https:// www.safeentry.gov.sg/ [Accessed 16 Jun 2020].

23 Ministry of Health. Stricter safe distancing measures to prevent further spread of COVID-19 cases, 2020. Available: https://www. moh.gov.sg/news-highlights/details/stricter-safe-distancingmeasures-to-prevent-further-spread-of-covid-19-cases [Accessed 13 Apr 2020].

24 Ministry of Communications and Information. Official COVID-19 sources, 2020. Available: https://www.gov.sg/article/covid-19resources [Accessed 18 May 2020].

25 Ang HM, Phua R. COVID-19: compulsory to wear mask when leaving the house, says Lawrence Wong. Channel News Asia, 2020. Available: https://www.channelnewsasia.com/news/singapore/ covid19-wearing-masks-compulsory-lawrence-wong-12640828 [Accessed 29 Jul 2020]

26 Enterprise Singapore. Guide on business continuity planning for COVID-19, 2020. Available: https://www.enterprisesg.gov.sg/-/ media/esg/files/covid-19/guide-on-business-continuity-planning-forcovid.pdf [Accessed 13 May 2020].

27 Ministry of Education. Schools and institutes of higher learning to shift to full home-based learning; preschools and student care centres to suspend general services, 2020. Available: https://www. moe.gov.sg/news/press-releases/schools-and-institutes-of-higherlearning-to-shift-to-full-home-based-learning-preschools-andstudent-care-centres-to-suspend-general-services [Accessed 29 Jul 2020].

28 Ministry of Education. Mid-year holidays brought forward as schools adjust academic calendar; Institutes of higher learning to extend home-based learning, 2020. Available: https://www.moe.gov. sg/news/press-releases/mid-year-holidays-brought-forward-asschools-adjust-academic-calendar-institutes-of-higher-learning-toextend-home-based-learning [Accessed 29 Jul 2020].

29 Choo YT. Coronavirus: Singapore government to foot bills of infected patients at public hospitals, except outpatient expenses. The Straits Times, 2020. Available: https://www.straitstimes.com/singapore/ health/coronavirus-government-to-foot-bills-of-infected-patients-atpublic-hospitals [Accessed 12 Apr 2020].

30 TODAY online. Singaporeans who travel overseas after March 27 to pay full hospital rates if warded for COVID-19, 2020. Available: https://www.todayonline.com/singapore/singaporeans-whotravel-overseas-after-march-27-pay-full-hospital-rates-if-they-are [Accessed 12 Apr 2020].

31 Ministry of Finance Singapore. Budget 2020: budget measures, 2020. Available: https://www.singaporebudget.gov.sg/budget_2020/ budget-measures [Accessed 12 Jun 2020].

32 Singapore Healthcare Corps. Join the SG Healthcare Corps, 2020. Available: https://healthcarecorps.gov.sg/ [Accessed 12 Apr 2020].

33 Goh K-T, Cutter J, Heng B-H, et al. Epidemiology and control of SARS in Singapore. Ann Acad Med Singap 2006;35:301-16.

34 Health Sciences Authority. Import of hand sanitisers, masks, thermometers and protective gear, 2020. Available: https://www. hsa.gov.sg/announcements/regulatory-updates/import-of-handsanitisers-masks-thermometers-and-protective-gear [Accessed 13 Apr 2020].

35 Lin C. COVID-19: gaming firm Razer to give out about 5 million free masks to Singapore residents. Channel News Asia, 2020. Available: https://www.channelnewsasia.com/news/singapore/razer-freemasks-vending-machines-covid-19-12722200 [Accessed 13 May 2020].

36 Tan A. Developing tests to diagnose COVID-19 in minutes. The Straits Times, 2020. Available: https://www.straitstimes.com/ singapore/health/developing-tests-to-diagnose-covid-19-in-minutes [Accessed 4 May 2020].

37 BioSpectrum Asia. Biolidics launches rapid test kit for COVID-19 2020. Available: https://www.biospectrumasia.com/news/26/15878/ biolidics-launches-rapid-test-kit-for-covid-19-.html [Accessed 5 May 2020].

38 BioSpectrum Asia. Singapore creates world's first IOT-enabled televentilator, 2020. Available: https://www.biospectrumasia.com/news/ 54/15812/singapore-creates-worlds-first-iot-enabled-tele-ventilator. html [Accessed 24 Apr 2020].

39 Chong C. Patients who are well but still testing positive for COVID-19 to be moved to community isolation facility to preserve hospital capacity. The Straits Times, 2020. Available: https://www. straitstimes.com/singapore/patients-who-are-well-but-still-testingpositive-for-covid-19-to-be-moved-to-community [Accessed 17 April 2020].

40 Ahmed S, Tan WLG, Chong Y-L. Surgical response to COVID-19 pandemic: a Singapore perspective. J Am Coll Surg 2020;230:1074-7.

41 Kurohi R. Free medicine delivery for SingHealth patients until june 30; \$8 afterwards. 2020: The Straits Times, 2020. Available: https:// www.straitstimes.com/singapore/health/medicine-delivery-forsinghealth-patients [Accessed 12 Apr 2020].

42 The Straits Times. Telehealth start-up Doctor Anywhere raises $\$ 38.4 \mathrm{~m}$ for regional expansion, 2020. Available: https://www. straitstimes.com/business/companies-markets/telehealth-start-updoctor-anywhere-raises-384m-for-regional-expansion [Accessed 24 Apr 2020].

43 Teo J. Extra protection for healthcare workers doing large-scale COVID-19 tests. The Straits Times, 2020. Available: https://www. straitstimes.com/singapore/extra-protection-for-healthcare-workersdoing-large-scale-covid-19-tests [Accessed 24 Apr 2020].

44 Baker JA. 66 COVID-19 cases among healthcare workers and support staff: Gan Kim Yong. Channel News Asia, 2020. Available: https://www.channelnewsasia.com/news/singapore/66-covid-19cases-among-healthcare-workers-and-support-staff-gan-12700342 [Accessed 4 May 2020]. 
45 The Straits Times. Nearly 17,000 Italian health workers infected with virus: study, 2020. Available: https://www.straitstimes.com/world/ europe/nearly-17000-italian-health-workers-infected-with-virusstudy [Accessed 18 May 2020].

46 Ministry of Health. COVID-19 (Temporary Measures) (Control Order) regulations, 2020. Available: https://www.moh.gov.sg/policiesand-legislation/covid-19-(temporary-measures)-(control-order)regulations [Accessed 12 Apr 2020].

47 Kuguyo O, Kengne AP, Dandara C. Singapore COVID-19 pandemic response as a successful model framework for low-resource health care settings in Africa? OMICS 2020;24:470-8.

48 Ministry of Communications and Information. What do the different DORSCON levels mean, 2020. Available: https://www.gov.sg/article/ what-do-the-different-dorscon-levels-mean [Accessed 17 Apr 2020]

49 Low Y, Alif $C$. The big read: panic buying grabbed the headlines, but a quiet resilience is seeing Singaporeans through COVID-19 outbreak, 2020. Available: https://www.channelnewsasia.com/news/ singapore/coronavirus-covid-19-panic-buying-singapore-dorsconorange-12439480 [Accessed 12 Apr 2020].

50 Mahmud AH. COVID-19 social media vigilantes: A valid or harmful way of dealing with rule breakers? : Channel News Asia, 2020. Available: https://www.channelnewsasia.com/news/singapore/covid19-online-social-media-vigilante-expose-viral-covidiot-12814476 [Accessed 29 Jul 2020].

51 Mohan M. COVID-19 circuit breaker extended until Jun 1 as Singapore aims to bring down community cases 'decisively': PM Lee, 2020. Available: https://www.channelnewsasia.com/news/ singapore/covid-19-circuit-breaker-extended-june-pm-lee-speechapr-21-12662054 [Accessed 21 Apr 2020].
52 Ministry of Manpower Singapore. Inter-agency Taskforce to support foreign workers and dormitory operators during circuit breaker period, 2020. Available: https://www.mom.gov.sg/newsroom/pressreleases/2020/0407-inter-agency-taskforce-to-support-fws-anddormitory-operators-during-circuit-breaker-period [Accessed $14 \mathrm{Apr}$ 2020]

53 Toh TW. 5,000 more foreign workers to be tested for COVID-19, 2020. Available: https://www.straitstimes.com/singapore/health/ 5000-more-foreign-workers-to-be-tested-for-covid-19 [Accessed 17 Apr 2020].

54 Martime and Port Authority of Singapore. Singapore to add floating accommodation to range of housing for foreign workers, 2020. Available: https://www.mpa.gov.sg/web/portal/home/media-centre/ news-releases/detail/6c4510c3-0527-4dc6-b687-cc8dfc0ad001 [Accessed 14 Apr 2020].

55 Nadarajan R. New dorms with 'better standards' to be built for 100,000 foreign workers in coming years: Lawrence Wong, 2020. Available: https://www.todayonline.com/singapore/new-dormsbetter-standards-be-built-100000-foreign-workers-coming-yearslawrence-wong [Accessed 16 Jun 2020].

56 Sin Y. Some new quick build dorms can be completed in four months. The Straits Times, 2020. Available: https://www.straitstimes. com/singapore/some-new-quick-build-dorms-can-be-completed-infour-months [Accessed 29 Jul 2020].

57 Ministry of Communications and Information. Ending circuit breaker: phased approach to resuming activities safely, 2020 Available: https://www.gov.sg/article/ending-circuit-breakerphased-approach-to-resuming-activities-safely [Accessed 16 Jun 2020]. 